\title{
The intake of milk by suckled, newborn lambs and the effects of twinning and cold exposure
}

\author{
BY G. E. THOMPSON \\ Agricultural Research Council Institute of Animal Physiology, Babraham, \\ Cambridge CB2 4AT
}

(Received 5 November 1982 - Accepted 10 February 1983)

\begin{abstract}
1. Clun Forest ewes with single and twin lambs were exposed to neutral $\left(20^{\circ}\right)$ or cold $\left(-1^{\circ}\right)$ environmental temperatures, beginning soon after parturition, for $4 \mathrm{~d}$. The intakes of milk, lactose and glycerides by the lambs were calculated from measurements of the rate of displacement of tritiated water (injected into the lambs) by non-radioactive water in milk from the ewes, and measurements of the concentration of lactose and glyceride glycerol in small samples of milk.

2. The yield of milk from ewes bearing twin lambs was greater than the yield from single-bearing ewes in the neutral environment but, in both environments, twin lambs had lower intakes of milk and milk lactose and glycerides, and gained body-weight more slowly, than single lambs. Milk from twin-bearing ewes had a lower lactose concentration than milk from single-bearing ewes.

3. Cold exposure reduced the intake of milk and milk lactose, and reduced the rate of weight gain, of single and twin lambs. Glyceride intake was not different in the two environments.

4. There appears to be a conflict between reduced supply of milk by the ewe and increased demand for milk by the lamb in cold temperatures. Such a conflict is sharpened when twin lambs are born.
\end{abstract}

The primary causes of mortality in newborn lambs are difficult to distinguish from their sequelae, but depletion of body fat is a common post-mortem finding (Houston \& Maddox, 1974) and starvation and exposure are considered to be major causes of mortality in lambs in the north of Scotland (Johnston et al. 1980). The first few days of life are a critical time for survival, particularly of twin lambs.

In the present experiment, the intake of milk by newborn, sucking, Clun Forest lambs has been measured, and the intake by single and twin lambs compared in neutral $\left(\simeq 20^{\circ}\right)$ and cold $\left(\simeq-1^{\circ}\right)$ environmental temperatures. It is known that exposure of hand-milked, high-yielding, Friesland sheep to a cold environment $\left(1^{\circ}\right.$ and wool depth of $5 \mathrm{~mm}$ ) late in lactation reduces their secretion of milk (Thompson et al. 1981). In contrast, exposure of young (aged 1-23 d) bottle-fed lambs to a cold $\left(7^{\circ}\right)$ environment increases their voluntary intake of milk-substitute (Gibb \& Penning, 1972). The conditions of cold exposure that were employed in the present experiment, $-1^{\circ}$ and the ewe's coat clipped to a depth of about $5 \mathrm{~mm}$, were designed to produce cold, i.e. subcritical, environments for both the ewe (Armstrong et al. 1960) and its offspring (Alexander, 1961). Treatment was begun after parturition in order to avoid the complication of cold exposure in late pregnancy delaying parturition (Samson et al. 1983).

\section{MATERIALS AND METHODS}

Animals. Nineteen Clun Forest ewes of known parity were used. All were mated with Clun Forest rams and dates of mating noted. Each ewe was clipped to a coat depth of about $5 \mathrm{~mm}$, after 133-136 d of pregnancy, and then housed in an individual pen at an environmental temperature of $20^{\circ}$ and given $900 \mathrm{~g}$ concentrates and $1 \mathrm{~kg}$ chopped hay daily in a single meal given at about 15.00 hours. After parturition, a small (approximately $2 \mathrm{ml}$ ) sample of milk was manually expressed from the ewe. The lambs were weighed and a sample (1-2 ml) of blood taken from them through a needle inserted into a recurrent tarsal vein; 
tritiated water was then injected intramuscularly, $2 \mathrm{~h}$ was allowed for it to equilibrate with body water (Macfarlane et al. 1969) and a second blood sample taken. Ewe and offspring were randomly assigned to a pen at either approximately $20^{\circ}$ (range $18-22^{\circ}$ ) or $-1^{\circ}$ (range -3 to $-1^{\circ}$ ): six ewes with single lambs, three ewes with twin lambs and one ewe with triplets were kept at the neutral temperature, while six ewes with single lambs and three ewes with twin lambs were exposed to the cold temperature. The floor of each pen was covered with wood shavings. Feeding of the ewes was continued as before parturition and water placed in a position where it was accessible to the ewe only, slightly warmed in the cold temperature to prevent freezing. Milk samples were taken from the ewe at approximately 09.00 and 21.00 hours daily, and blood samples taken from lambs at least once daily, for $4 \mathrm{~d}$. At the end of this time, lambs were again weighed, injected with tritiated water and a blood sample taken after this injectate had equilibrated with body water. Blood was also taken from a jugular vein of the ewe.

Tritiated water (Amersham International, Amersham, Bucks) was prepared for injection by diluting with sterile saline $(9 \mathrm{~g}$ sodium chloride/l) so that $100 \mu \mathrm{Ci}$ was contained in approximately $3 \mathrm{ml}$. The volume injected varied from 3.5 to $5.5 \mathrm{ml}$, depending on body-weight of the lamb. Injections were deep $(25 \mathrm{~mm})$ into muscle using a fine ( 23 gauge) needle and the syringe plus needle weighed before and after injection. Blood plasma samples, and a standard solution of injectate diluted in water, were mixed with $0.33 \mathrm{M}$-perchloric acid, to precipitate protein in the plasma, and centrifuged. The clear, supernatant fraction was used for liquid scintillation counting.

Milk. Milk samples were dried over silica gel to a constant weight, to measure their water content. The concentration of lactose in milk was measured using an automatic analyser (Fleet et al. 1972). The concentration of glyceride glycerol in milk was measured by extracting the glycerides from $0.2 \mathrm{ml}$ fresh milk into $20 \mathrm{ml}$ chloroform-methanol $(2: 1, \mathrm{v} / \mathrm{v})$ for at least $1 \mathrm{~h}$ and then adding $20 \mathrm{ml}$ distilled water. This mixture was shaken and allowed to separate into aqueous and organic phases overnight at $4^{\circ}$ (Folch et al. 1957). Glycerides in $0.2 \mathrm{ml}$ of the organic infranatant were hydrolysed by mixing with $0.5 \mathrm{ml} 0.5 \mathrm{M}$-glycerol-free ethanolic potassium hydroxide and heating to $55^{\circ}$ for $30 \mathrm{~min}$. After cooling, $1 \mathrm{ml}$ $0.15 \mathrm{M}$-magnesium sulphate in water was added, the mixture shaken and then centrifuged. The glycerol content of the aqueous supernatant fraction was measured using the enzyme glycerol kinase (EC 2.7.1.30; Eggstein \& Kuhlmann, 1974).

Calculations. Total body water volume of each lamb was calculated from dilution of radioactivity in the tritiated water injection, at the beginning and end of the experiment. It was assumed that change of volume during the experiment was linear and a body water volume for each day was calculated; the rate of water intake into the lamb was calculated from body water volume and rate of change of specific radioactivity of plasma (Dove \& Freer, 1979). The rate of intake of milk was calculated from the rate of intake of water and mean water content of milk samples taken in the same time interval. Intake of lactose and glyceride glycerol was calculated from milk intake and the concentrations of those nutrients in milk.

The significance of differences due to twinning and cold exposure was assessed using the two-factor analysis of variance. The significance of changes with time within animals was assessed using the Student's paired $t$ test.

\section{RESULTS}

No radioactivity above background was detected in maternal blood samples and so it was assumed that there was no radioactivity in the milk of the ewes.

Fig. 1 shows the change of composition of milk samples that were taken from six ewes, each nursing a single lamb and exposed to a neutral temperature, during $4 \mathrm{~d}$ after delivery. 


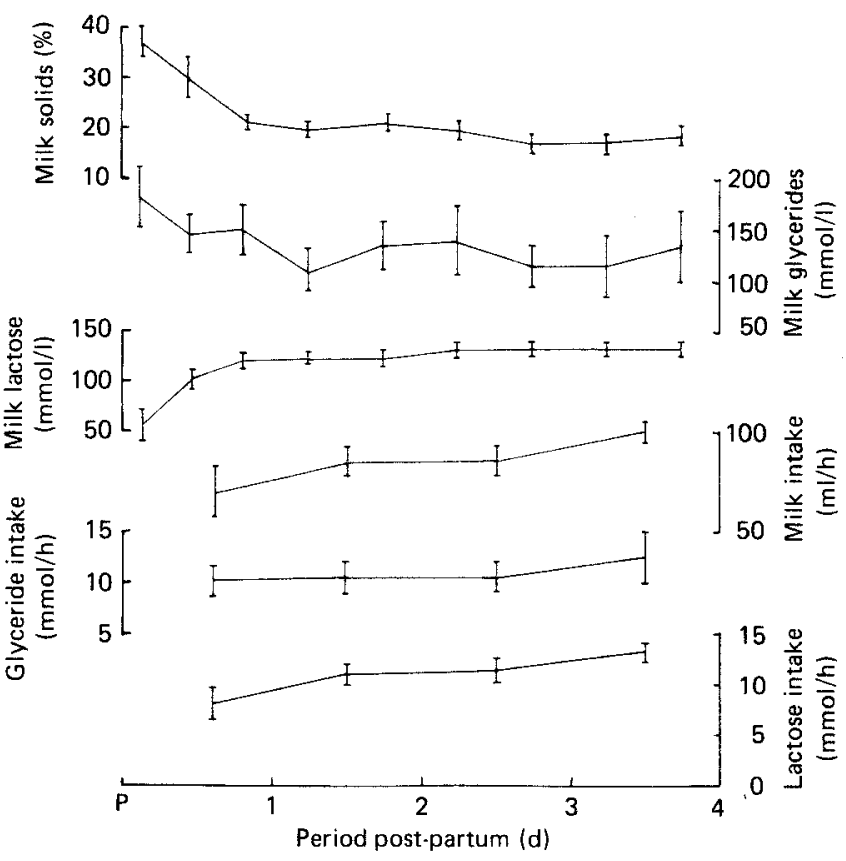

Fig. 1. Change of milk composition of six ewes, and intake of milk and milk constituents by their single lambs, in a neutral $\left(20 \pm 2^{\circ}\right)$ environmental temperature during the first $4 \mathrm{~d}$ post-partum. Points are mean values with their standard errors represented by vertical bars.

The percentage of milk that was solids fell significantly with time. The difference between the mean percentage of solids in the period $0-12 \mathrm{~h}$ post-partum and the corresponding value in the period $12 \mathrm{~h}-2.5 \mathrm{~d}$ post-partum was $11 \%$ (standard error of the difference 2.8 ; $P<0.02)$. There was also a difference between the values obtained $12 \mathrm{~h}-2.5 \mathrm{~d}$ post-partum and those obtained from $2.5 \mathrm{~d}$ to $4 \mathrm{~d}$ post-partum, of $2.5 \%$ (SED $0.87 ; P<0.05$ ). The concentration of lactose in milk increased significantly with time. The difference between mean concentration in the period $0-12 \mathrm{~h}$ and in the period $12 \mathrm{~h}-2 \mathrm{~d}$ was $37 \mathrm{mmol} / \mathrm{l}$ (SED 6.9; $P<0.001)$. There was a further change between $12 \mathrm{~h}-2 \mathrm{~d}$ and $2 \mathrm{~d}-4 \mathrm{~d}$, of $11 \mathrm{mmol} / 1$ (SED $4.2 ; P<0.05$ ). Intake of milk did not change significantly with age, but five of the six lambs had a slower rate of intake of milk on the first day of life than on the fourth day.

Table 1 contains mean values for the composition of milk in the time between parturition and $4 \mathrm{~d}$ after delivery, and for the intake of milk by lambs between $6 \mathrm{~h}$ and $4 \mathrm{~d}$ after delivery; estimates of milk intake during the first $6 \mathrm{~h}$ of life were not attempted.

The yields of milk from ewes that were bearing a single lamb and from ewes that were bearing twin lambs were similar in the cold environment, but in the neutral environment the yield from twin-bearing ewes was significantly greater $(P<0.001)$. Milk from twinbearing ewes, in both environments, had a significantly lower lactose concentration than milk from single-bearing ewes. Twin lambs had a significantly slower intake of milk and milk lactose and glycerides, and slower weight gain, than single lambs. The twin lamb which was heavier at birth often, but not always, had a greater intake of milk and weight gain than its lighter litter-mate.

A uniparous ewe produced triplets and was kept in a neutral environment for $4 \mathrm{~d}$ after parturition. Its mean yield of milk during this time was $138 \mathrm{ml} / \mathrm{h}$ and the mean composition of the milk was $21 \%$ solids, $117 \mathrm{mmol}$ lactose $/ 1$ and $136 \mathrm{mmol}$ glycerides $/ 1$.

Exposure to cold significantly reduced the intake of milk and milk lactose, and reduced 
G. E. THOMPSON

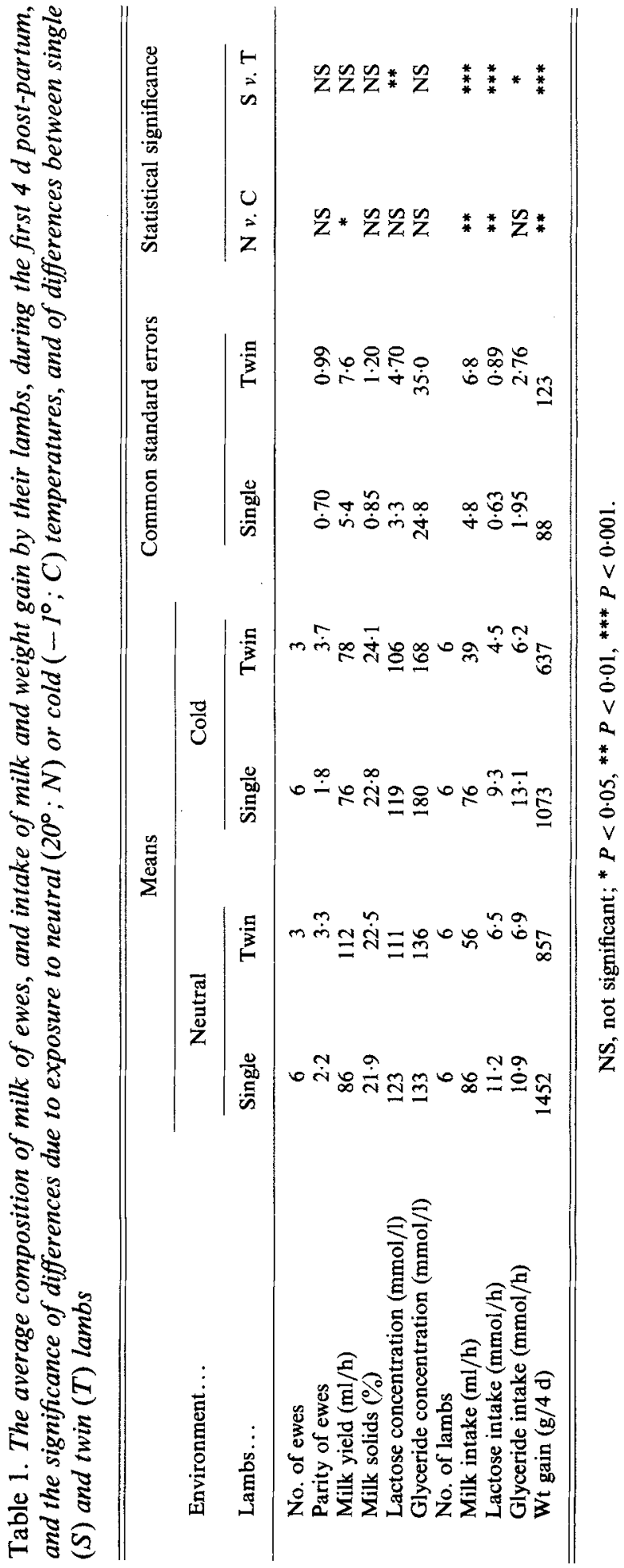


the rate of weight gain, of single and twin lambs. The concentration of glycerides in milk was slightly, though not significantly, higher in the cold environment and glyceride intake of the lambs was not different in the two environments.

None of the effects of cold exposure and twinning interacted significantly.

\section{DISCUSSION}

The change of milk composition observed at the beginning of lactation in the neutral environment was similar to the changes which have been observed in sheep previously (Hartmann et al. 1973; Thompson \& Goode, 1981). The volumes of milk that were sucked from control ewes at the beginning of lactation were higher than those previously obtained from Merino ewes that were hand-milked at the beginning of lactation (McCance \& Alexander, 1959) but comparable to the volumes obtained by hand-milking other breeds (Peart et al. 1975). The difference of concentration of lactose in milk between single- and twin-bearing ewes, observed in the present experiment, has no obvious explanation and does not agree with similar measurements on hand-milked ewes in which there was no difference (Peart et al. 1975).

Newborn lambs are more susceptible to a given cold environmental temperature than adult ewes, mostly because the fleece length and, therefore, insulating value of their coats is different. Thus, there is a range of low environmental temperatures in which the lamb has an increased energy expenditure, to maintain body temperature, but the ewe does not. In these conditions the flow of milk, and therefore energy, available to the lamb may remain at control levels because the ewe is not affected by the environment.

A different situation exists when the environment is sufficiently cold to affect both ewe and lamb. This is most likely to occur naturally when windy (Joyce \& Blaxter, 1964) and wet (Joyce et al. 1966) weather partially destroys the insulating properties of the fleece. In the present experiment this was achieved by clipping the ewes, which made it possible to cold stress the ewe (Armstrong et al. 1960) without producing an extreme cold stress for the lamb (Alexander, 1961). In these conditions, the expenditure of energy by the lambs was increased but their intake of milk was reduced. The milk intake of twin lambs was reduced by cold exposure, below the low levels caused by sharing a milk source, and the weight gain of twins was most markedly affected by cold exposure. To some extent the reduced intake of milk volume in the cold may have been compensated by an increased fat content of the milk. In a previous, similar experiment, cold exposure produced a clear increase in milk-fat concentration (Thompson \& Goode, 1981), but the results of the present experiment are not clear on this point.

The reduced yield of milk by the ewes to their offspring, in the cold environment, was most likely a result of reduced milk secretion. It has been reported that cold exposure reduces the teat-seeking activity of lambs, particularly when severe enough to cause hypothermia (Alexander \& Williams, 1966), but in the present experiment little reserve milk appeared to be stored in the sinus of the udder, and the lambs had a strong drive to suck in the cold environment. This is in accord with the observation of increased consumption of milk by bottle-fed lambs in a cold environment (Gibb \& Penning, 1972).

The physiological mechanisms that reduce milk secretion during cold exposure have been studied in goats that have an established lactation. The most important is a reduction of mammary extraction of glucose from the circulation which is, in turn, most likely brought about by cortisol (Faulkner et al. 1980). It is less likely that cortisol has such a role at the initiation of lactation because cortisol injection stimulates an early lactogenesis in latepregnant sheep (Martal \& Djiane, 1977).

In conclusion, cold exposure appears to produce a conflict between reduced supply of milk by the ewe and increased demand for milk by the lambs. The consequences of such 
a conflict are likely to be more evident in twin lambs than single lambs. Important among the likely sequelae to undernutrition of lambs in a cold environment are a reduced capacity for thermogenesis (Alexander, 1962) and hypothermia. This restriction of the supply of nutrients to the lamb after birth, and its consequent risk to lamb survival, contrasts with the extra supply of nutrients to the fetal lamb when the late-pregnant ewe is cold exposed (Thompson et al. 1982).

\section{REFERENCES}

Alexander, G. (1961). Australian Journal of Agricultural Research 12, 1152-1174.

Alexander, G. (1962). Australian Journal of Agricultural Research 13, 100-121.

Alexander, G. \& Williams, D. (1966). Journal of Agricultural Science, Cambridge 67, 181-189.

Armstrong, D. G., Blaxter, K. L., Clapperton, J. L., Graham, N. McC. \& Wainman, F. W. (1960). Journal of Agricultural Science, Cambridge 55, 395-401.

Dove, H. \& Freer, M. (1979). Australian Journal of Agricultural Research 30, 725-739.

Eggstein, M. \& Kuhlmann, E. (1974). In Methods of Enzymatic Analysis, pp. 1825-1831 [H. U. Bergmeyer, editor]. New York: Verlag Chemie.

Faulkner, A., Thomson, E. M., Bassett, J. M. \& Thompson, G. E. (1980). British Journal of Nutrition 43, $163-170$.

Fleet, I. R., Linzell, J. L. \& Peaker, M. (1972). British Veterinary Journal 128, 297-300.

Folch, J., Lees, M. \& Sloan-Stanley, G. H. (1957). Journal of Biological Chemistry 226, 497-509.

Gibb, M. J. \& Penning, P. D. (1972). Animal Production 15, 177-182.

Hartmann, P. E., Trevethan, P. \& Shelton, J. N. (1973). Journal of Endocrinology 59, 249-259.

Houston, D. C. \& Maddox, J. G. (1974). Veterinary Record 95, 575.

Johnston, W. S., Maclachlan, G. K. \& Murray, 1. S. (1980). Veterinary Record 106, 238-240.

Joyce, J. P. \& Blaxter, K. L. (1964). British Journal of Nutrition 18, 5-27.

Joyce, J. P., Blaxter, K. L. \& Park, C. (1966). Research in Veterinary Science 7, 342-359.

McCance, I. \& Alexander, G. (1959). Australian Journal of Agricultural Research 10, 699-719.

Macfarlane, W. V., Howard, B. \& Siebert, B. D. (1969). Nature 221, 578-579.

Martal, J. \& Djiane, J. (1977). Journal of Steroid Biochemistry 8, 415-417.

Peart, J. N., Edwards, R. A. \& Donaldson, E. (1975). Journal of Agriculturai Science, Cambridge 85, 315-324.

Samson, D. E., Slee, J., Thompson, G. E., Goode, J. A. \& Flint, A. P. F. (1983). Animal Production 36, 1-6.

Thompson, G. E., Bassett, J. M., Samson, D. E. \& Slee, J. (1982). British Journal of Nutrition 48, 59-64.

Thompson, G. E. \& Goode, J. A. (1981) Animal Production 32, 245-250.

Thompson, G. E., Hartmann, P. E., Goode, J. A. \& Lindsay, K. S. (1981). Comparative Biochemistry and Physiology 70A, 13-16. 